\title{
Angiotensin II Stimulates Proliferation of Normal Early Erythroid Progenitors
}

\author{
Michal Mrug, ${ }^{*}$ Tomas Stopka, ${ }^{*}$ Bruce A. Julian, ${ }^{\ddagger}$ Jaroslav F. Prchal, ${ }^{\S}$ and Josef T. Prchal ${ }^{\star}$ \\ $*$ Division of Hematology/Oncology, and ${ }^{\ddagger}$ Division of Nephrology, University of Alabama, Birmingham, Alabama 35294; and ${ }^{\S}$ Division \\ of Hematology, McGill University, Montreal, Canada H3T 1 M5
}

\begin{abstract}
Angiotensin II exerts a mitogenic effect in several in vitro models, but a direct effect on erythroid progenitors has not been documented. Angiotensin-converting enzyme inhibitors and losartan, an angiotensin II type 1 receptor $\left(\mathrm{AT}_{1}\right)$ antagonist, ameliorate posttransplant erythrocytosis, without altering serum erythropoietin levels. We studied erythroid differentiation and the effect of angiotensin II on proliferation of erythroid progenitors by culturing CD34+ hematopoietic progenitor cells in liquid serum-free medium favoring growth of erythroid precursors. Aliquots of cells were collected every third day, and were used for RNA preparation. $\mathrm{AT}_{1}$ mRNA was detected after $6 \mathrm{~d}$. In these same samples, erythroid-specific mRNA (erythropoietin receptor) was also detected. $\mathrm{AT}_{1}$ protein was detected in 7-d-old burst-forming units-erythroid colonies by Western blotting. The CD34+ cell liquid cultures were used to incubate erythroid precursors with angiotensin II from days 6-9. After incubation, cells were transferred to semisolid medium and cultured with erythropoietin. Angiotensin II increased proliferation of early erythroid progenitors, defined as increased numbers of burst-forming units-erythroid colonies. Losartan completely abolished this stimulatory effect of angiotensin II. Moreover, we observed increased numbers of erythroid progenitors in the peripheral blood of posttransplant erythrocytosis patients. Thus, activation of $\mathrm{AT}_{1}$ with angiotensin II enhances erythropoietin-stimulated erythroid proliferation in vitro. A putative defect in the angiotensin II/AT 1 pathway may contribute to the pathogenesis of posttransplant erythrocytosis. (J. Clin. Invest. 1997. 100: 2310-2314.) Key words: erythropoiesis - angiotensin receptor • erythrocytosis $\bullet$ polycythemia $\bullet$ kidney transplant
\end{abstract}

Dr. Mrug and Dr. Stopka contributed equally to this paper, and for purposes of authorship should be considered as first authors. This work was presented in part at the Annual Meeting of the American Society of Hematology, Orlando, FL, 5-10 December 1996, and was published in abstract form (1996. J. Am. Soc. Nephrol. 7:1930; and 1996. Blood. 88:646a).

Address correspondence to Josef Prchal, M.D., Department of Medicine, Division of Hematology/Oncology, 1900 University Boulevard, THT 513, Birmingham, AL 35294-0006. Phone: 205-934-2721; FAX: 205-934-1910; E-mail: jtprchal@bmg.bhs.uab.edu

Received for publication 24 January 1997 and accepted in revised form 24 July 1997.

J. Clin. Invest.

(C) The American Society for Clinical Investigation, Inc. 0021-9738/97/11/2310/05 \$2.00

Volume 100, Number 9, November 1997, 2310-2314

http://www.jci.org

\section{Introduction}

Erythropoiesis is the dynamic process of red blood cell production. After erythroid commitment of undifferentiated pluripotent hematopoietic stem cells, subsequent cellular divisions amplify the early erythroid progenitors, providing the proper quantity of cells for terminal differentiation into mature erythrocytes. While the influences regulating commitment to the erythroid lineage are not fully understood, erythropoietin is an obligatory growth factor, increasing the number of progenitors by stimulating erythroid mitogenesis and differentiation, and by preventing apoptosis. A wide variety of factors, however, also stimulate erythropoiesis, including insulin-like growth factor 1 (IGF-1), granulocyte-macrophage colony stimulating factor (GM-CSF), IL-6, IL-1, activin-A, and basic fibroblast growth factor $(1,2)$. Proliferation of the earliest primitive erythroid progenitors depends on growth factors not unique to erythropoiesis, of which IL-3 and stem cell factor may dominate $(3,4)$. Additional influences may modulate erythroid proliferation by acting directly on erythroid progenitors, or indirectly through release of erythropoietic growth factors from nonerythroid cells.

Angiotensin II, which has a mitogenic effect on smooth muscle cells $(5,6)$, may be one of these additional factors stimulating erythropoiesis, perhaps indirectly by increasing serum erythropoietin. Angiotensin-converting enzyme inhibitors decrease hematocrit in posttransplant erythrocytosis patients by mechanisms other than changes in circulating erythropoietin $(7,8)$. Losartan, an angiotensin II type 1 receptor $\left(\mathrm{AT}_{1}\right)^{1}$-specific antagonist, decreases hematocrits in patients with posttransplant erythrocytosis $(9,10)$.

To define how angiotensin II influences the red blood cell production, we studied expression of its receptor on erythroid progenitors and its effect on the in vitro proliferation of early erythroid progenitors. In addition, we studied early erythroid progenitors of posttransplant erythrocytosis patients, renal transplant recipients without erythrocytosis, and normal volunteers.

\section{Methods}

Early hematopoietic progenitor isolation and cell culture. Peripheral mononuclear cells from normal volunteers were isolated on a FicollHistopaque gradient (Sigma Chemical Co., St. Louis, MO). Undifferentiated early hematopoietic progenitors (CD34+ cells) were labeled and separated using a CD34+ cell magnetic sorting kit (Miltenyi Biotec Inc., Auburn, CA). The CD34+ cell fraction was cultured for $15 \mathrm{~d}$ in StemPro-34SFM serum-free media (Life Technologies, Inc., Gaithersburg, MD) in the presence of $3 \mathrm{IU} / \mathrm{ml}$ erythropoietin, $20 \mathrm{ng} / \mathrm{ml} \mathrm{stem}$ cell factor, and $20 \mathrm{ng} / \mathrm{ml}$ PIXY (a hybrid of IL-3 and GM-CSF), a

1. Abbreviations used in this paper: $\mathrm{AT}_{1}$, angiotension II type 1 receptor; BFU-E, burst-forming units-erythroid; EPOR, erythropoietin receptor; G6PD, glucose-6-phosphate dehydrogenase; RT-PCR, reverse transcription PCR. 
kind gift of Immunex Corp., Seattle, WA). Aliquots of $10^{5}$ cells were collected at 3-d intervals for RNA isolation.

Detection of $A T_{1} \quad m R N A$ by reverse transcriptase PCR (RT$P C R)$. Aliquots of CD34+ cells, cultured under conditions favoring erythroid differentiation (3 IU/ml erythropoietin, $20 \mathrm{ng} / \mathrm{ml}$ stem cell factor, and $20 \mathrm{ng} / \mathrm{ml}$ PIXY), were collected and stored. RNA was prepared using an RNeasy ${ }^{\mathrm{TM}}$ RNA isolation kit (QIAGEN Inc., Chatsworth, CA). After DNase treatment, synthesis of the corresponding cDNA was accomplished in one half aliquot of the cDNA using Superscipt II reverse transcriptase and DNase I (both purchased from Life Technologies, Inc.), according to manufacturer's recommendations. Because the full-length $\mathrm{AT}_{1}$ coding sequence is in the last exon (exon 5) of the $\mathrm{AT}_{1}$ gene (the other exons are alternatively spliced out), the $\mathrm{AT}_{1} \mathrm{PCR}$ amplifications were performed using RNA templates treated with reverse transcriptase $(\mathrm{RT}+)$ or without reverse transcriptase $(\mathrm{RT}-)$. PCR amplification of the $\mathrm{RT}-$ templates served as a control for possible DNA contamination. The $\mathrm{AT}_{1}$ sequence was amplified using outer primers $\mathrm{AT}_{1}-\mathrm{F}(541-561)$ : $5^{\prime}$-tttagcactggctgacttatg-3' and R-R(960-938): 5'-agaaaaggaaacaggaaaccca-3'; and nested primers $\mathrm{AT}_{1}-\mathrm{FN}(566-585): 5^{\prime}$-ttactgactttgccactatg- $3^{\prime}$ and $\mathrm{AT}_{1}-\mathrm{RN}(887-868): 5^{\prime}$-cataatggaaagcacaaact-3' with Taq polymerase (Life Technologies, Inc.) in a Model 480 thermocycler (Perkin-Elmer Corp., Norwalk, CT) for 30 cycles (the numbers after the primer name denote the position of the primers in the $\mathrm{AT}_{1}$ mRNA [GenBank accession S77410]). Each cycle consisted of 1 min denaturation at $95^{\circ} \mathrm{C}, 1 \mathrm{~min}$ annealing at $57^{\circ} \mathrm{C}$, and $2 \mathrm{~min}$ extension at $72^{\circ} \mathrm{C}$. Specificity of PCR amplification was confirmed by sequencing the subcloned PCR product. The same cDNA templates and PCR conditions as those for amplification of the mRNA for $\mathrm{AT}_{1}$ were used for detecting mRNA for the erythropoietin receptor (EPOR), except for primers EPOR-1/2F: 5'-caagttcgagagcaaagcggcct-3' and EPOR-6/7R: 5'agagcccggcggtgggagagcag- $3^{\prime}$, and reverse nested primer EPOR-4/5R: $5^{\prime}$-ctccaggatctccaccctctgta- $3^{\prime}$, and annealing at $60^{\circ} \mathrm{C}$. The quality of RNA preparation and cDNA synthesis was confirmed for all PCR templates by amplifying a ubiquitously expressed housekeeping gene, glucose-6-phosphate dehydrogenase (G6PD) (11) under the same conditions as those used for $\mathrm{AT}_{1}$ amplification.

Western blotting of the burst-forming units-erythroid (BFU-E) colonies lysates. Human bone marrow mononuclear cells were cultured in methylcellulose semisolid medium (MethoCult H-4531; Stem Cell Technologies, Vancouver, British Columbia) in 35-mm Petri dishes with $3 \mathrm{IU} / \mathrm{ml}$ of recombinant human erythropoietin (Life Technologies, Inc.). Cultures were maintained in a humidified atmosphere at $5 \% \mathrm{CO}_{2}, 21 \% \mathrm{O}_{2}$ at $37^{\circ} \mathrm{C}$. BFU-E colonies were scored at days 2,7 , and 14 using standard criteria $(12,13)$. Individual BFU-E colonies were harvested from semisolid cultures at day 7 , washed in $1 \times$ PBS, and lysed in lysis buffer containing $300 \mathrm{nM} \mathrm{NaCl}, 50 \mathrm{mM}$ Tris $\mathrm{HCl}$, pH 7.6, and 0.5\% Triton X-100 (Sigma Chemical Co.), for 30-45 min on ice. After a 15 -min centrifugation at $10,000 \mathrm{~g}$, the supernatant containing solubilized membranes as well as cytosolic material was denatured for $5 \mathrm{~min}$ at $95^{\circ} \mathrm{C}$ in $2 \times$ Laemmli buffer, and was separated by $10 \%$ SDS-PAGE (14). The gel was electrophoretically transferred onto a $0.45-\mu \mathrm{m}$ nitrocellulose membrane (Schleicher and Schuell, Inc., Keene, NH) using semidry blotter (Bio-Rad Laboratories, Hercules, CA) (15). The membrane was blocked with $5 \%$ nonfat milk in $1 \times$ PBS $/ 0.05 \%$ Tween- 20 overnight at $4{ }^{\circ} \mathrm{C}$. Subsequent washing and dilutions were with $1 \times \mathrm{PBS} / 0.05 \%$ Tween- 20 at room temperature. The primary rabbit anti- $\mathrm{AT}_{1}$ polyclonal antibody (Santa Cruz Biotechnology, Santa Cruz, CA) was detected by peroxidase-linked antirabbit antibody (Amersham Corp., Arlington Heights, IL). Activated chemiluminescence was detected on $\mathrm{x}$ ray film (Eastman Kodak Co., Rochester, NY) and was developed in a RP X-omat processor (Eastman Kodak Co.).

Stimulation of proliferation of early erythroid progenitors with angiotensin II in vitro and its inhibition by losartan, an AT $T_{1}$ antagonist. Early hematopoietic progenitors (CD34+ cells) from normal volunteers were isolated and cultured in serum-free media with $3 \mathrm{IU} / \mathrm{ml}$ erythropoietin, $20 \mathrm{ng} / \mathrm{ml} \mathrm{stem} \mathrm{cell} \mathrm{factor,} \mathrm{and} 20 \mathrm{ng} / \mathrm{ml}$ PIXY, as de- scribed above. To evaluate a dose-dependent response of erythroid progenitors to angiotensin II, the cells were harvested on day 6 (a day on which earlier results had shown an appearance of $\mathrm{AT}_{1}$ transcript), and were divided into aliquots. Aliquots containing 50,000 cells were cultured under the same conditions as before for three more days with various concentrations of angiotensin II $(0,1$, and $100 \mathrm{nM}$, and 10 and $100 \mathrm{nM}$ ) added every $12 \mathrm{~h}$. On day 9 the cells were washed with PBS, and were plated into methylcellulose semisolid media (MethoCult H4531) containing 0 or $3 \mathrm{IU} / \mathrm{ml}$ erythropoietin. The BFU-E colonies were scored $14 \mathrm{~d}$ after plating. To demonstrate that proliferation of erythroid progenitors was angiotensin II-specific, CD34+ cells were cultured in serum-free Stem Pro-34SFM media with $3 \mathrm{IU} / \mathrm{ml}$ erythropoietin, $20 \mathrm{ng} / \mathrm{ml}$ stem cell factor, and $20 \mathrm{ng} / \mathrm{ml}$ PIXY for $9 \mathrm{~d}$. Combinations of angiotensin II $(0$ and $100 \mathrm{nM})$ and losartan $(0,20$, and $200 \mathrm{nM})$ were added every $12 \mathrm{~h}$ to the cultures on days 6-9. The BFU-E colonies were scored $14 \mathrm{~d}$ after plating.

Stimulation of proliferation of BFU-E-derived erythroid progenitors with angiotensin II. Normal early hematopoietic progenitors (CD34+ cells) were plated into MethoCult H4531-containing combinations of angiotensin II $(0$ and $100 \mu \mathrm{M})$ and erythropoietin $(0$, $0.06,0.125,0.25,0.5,1$, and $3 \mathrm{IU} / \mathrm{ml})$. BFU-E colonies were scored $14 \mathrm{~d}$ after plating.

Detection of numbers of BFU-Es in renal transplant recipients. Peripheral blood mononuclear cells were plated into MethoCult $\mathrm{H} 431$ containing erythropoietin $(0,0.03,0.06,0.125,0.25,0.5,1$, and 3 $\mathrm{IU} / \mathrm{ml})$. BFU-E colonies of four posttransplant patients with erythrocytosis and of eight renal transplant recipients without erythrocytosis were scored after $14 \mathrm{~d}$. Each experiment was performed with identically handled peripheral blood mononuclear cells from normal individuals.

This study was approved by the Institutional Review Board for Human Use at the University of Alabama at Birmingham. Informed written consent was obtained from all subjects.

\section{Results}

Detection of $m R N A s$ for $A T_{1}$ and erythropoietin receptor in cultures favoring differentiation to early erythroid progenitors. Using nested RT-PCR with CD34+-derived progenitors, cells harvested at days 6,9 , and 12 had detectable $\mathrm{AT}_{1}$ mRNA. This transcript was detected concomitantly with mRNA for the erythropoietin receptor (Fig. 1). No mRNA for $\mathrm{AT}_{1}$ or the erythropoietin receptor was detected on days 0-5. mRNA for G6PD was detected in every sample, confirming the adequacy of RNA and cDNA preparation, and served as a positive control in all cDNA samples.

Detection of $A T_{1}$ protein in BFU-E colonies. About 500 BFU-E colonies were individually harvested under direct vision with aid of an inverted microscope (16), and were processed for Western blot analysis. These BFU-E colonies contained $\mathrm{AT}_{1}$ protein, as detected by anti- $\mathrm{AT}_{1}$ antibodies (Fig. 2). Mononuclear leukocytes that constitutively express $A_{1}$ (17) were used as a positive control. These data indicate that $\mathrm{AT}_{1}$ is present on BFU-E-derived erythroid progenitors.

Angiotensin II augments erythropoiesis. Angiotensin II added to $\mathrm{CD} 34+$ cultures on days six and nine increased the number of BFU-E colonies. A dose-dependent effect was observed when the angiotensin II concentration ranged from $10 \mathrm{nM}-100$ $\mu \mathrm{M}$ (Fig. 3). Losartan abolished this stimulatory effect of angiotensin II (Fig. 4). Addition of angiotensin II before day 6 or after day 9 had only a minor or no discernible effect on the number of BFU-E colonies (data not shown). A possible direct effect of angiotensin II on the formation of BFU-E colonies was examined by adding angiotensin II to methylcellulose cultures containing different erythropoietin concentrations. 


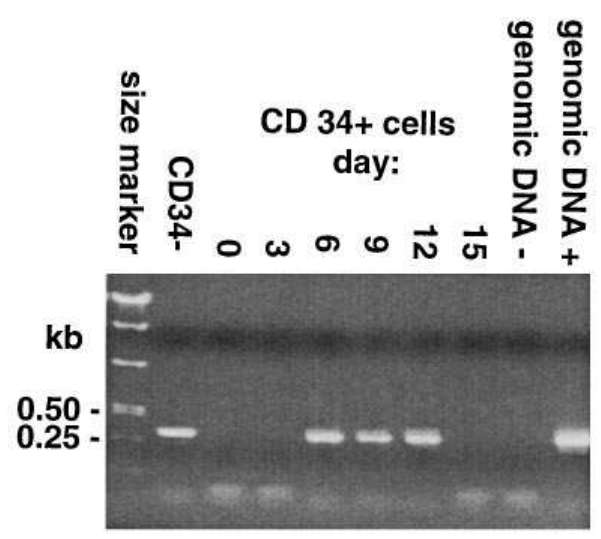

$\mathrm{AT}_{1}$

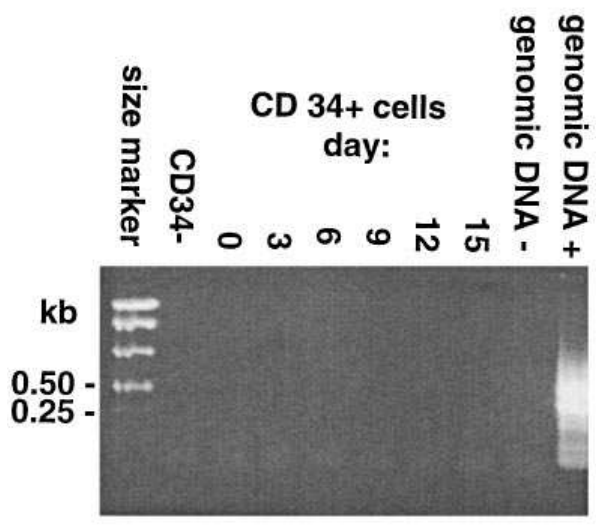

$\mathrm{AT}_{1}$ RT-

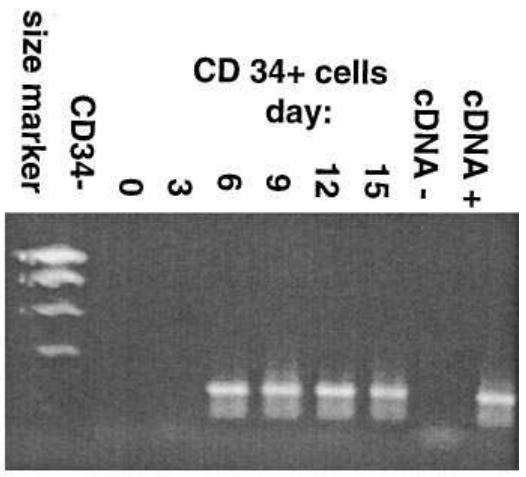

EPOR

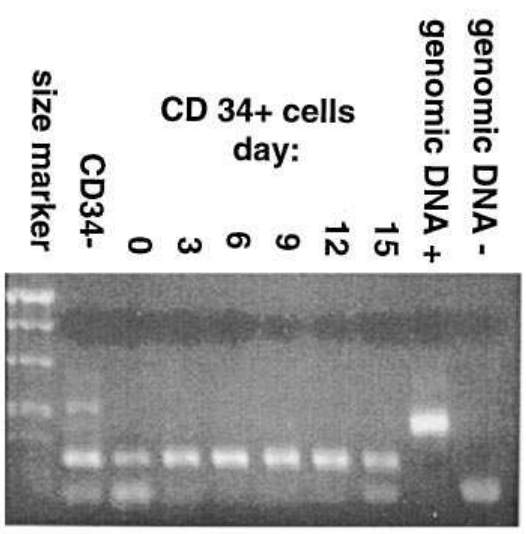

G6PD
Figure 1. Search for the transcripts of $\mathrm{AT}_{1}$ in differentiating hematopoietic stem cells. The angiotensin II type 1 receptor transcript (top left, $\mathrm{AT}_{1}$ ) was detected by RT-PCR in early hematopoietic progenitors cultured in vitro with erythropoietin, stem cell factor, and PIXY at days 6-12. Aliquots of the same reaction mixtures were also processed without addition of reverse transcriptase (RT-, bottom left) to rule out DNA contamination. The RTPCR for EPOR was used as a control for erythroid commitment, and RT-PCR for G6PD (an ubiquitously expressed housekeeping gene) was used as a quality control for the mRNA isolation and cDNA synthesis (bottom right).
BFU-Es grown with or without angiotensin II showed no appreciable differences in colony size or morphology.

Angiotensin II does not cause formation of erythropoietinindependent BFU-E colonies. In the absence of erythropoietin, no BFU-E colonies were observed when plating the pro-

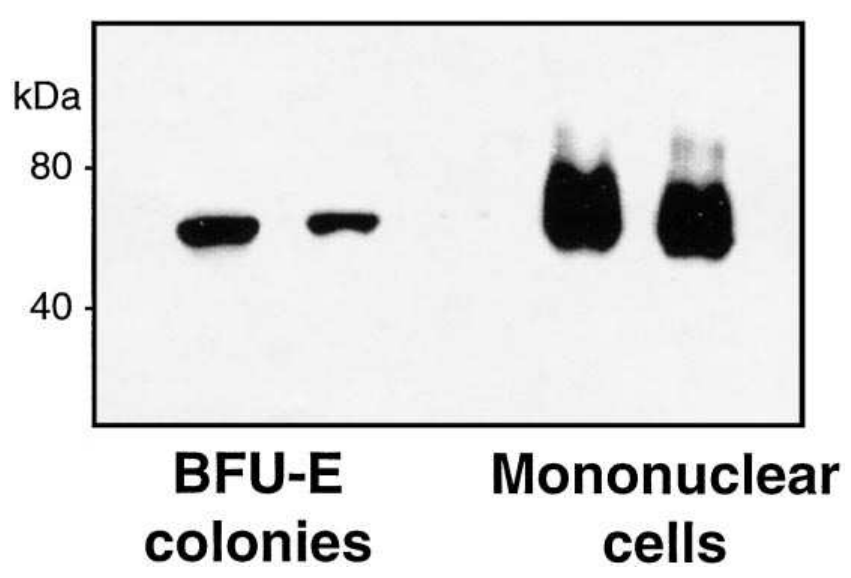

Figure 2. $\mathrm{AT}_{1}$ protein is present in $\mathrm{BFU}-\mathrm{E}$ colonies. The $\mathrm{AT}_{1}$ protein was detected in lysates of 7-d-old BFU-E colonies by Western blotting with antibody against epitope corresponding to amino acids 306359 of $\mathrm{AT}_{1}$. Mononuclear cells expressing $\mathrm{AT}_{1}$ were used as a positive control. genitors under optimal angiotensin II concentrations (see paragraph above). Thus, the stimulatory effect of angiotensin II did not substitute for that of erythropoietin in the development of BFU-E colonies.

Posttransplant erythrocytosis patients have increased numbers of erythroid progenitors in peripheral blood. Each posttransplant erythrocytosis patient was tested with identically handled normal control. No erythropoietin-independent BFU-E colonies were observed in posttransplant patients or in normal controls. The sensitivity of erythroid progenitors of posttrans-

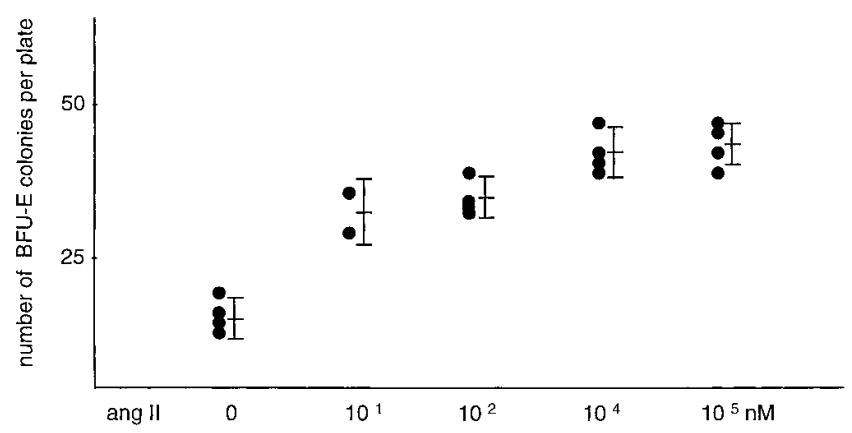

Figure 3. Angiotensin II (ang II) augments number of BFU-Es. Preincubation of early hematopoietic progenitors with angiotensin IIaugmented proliferation of early erythroid precursors in the presence of maximal stimulatory concentration of erythropoietin (3 IU/ml). 


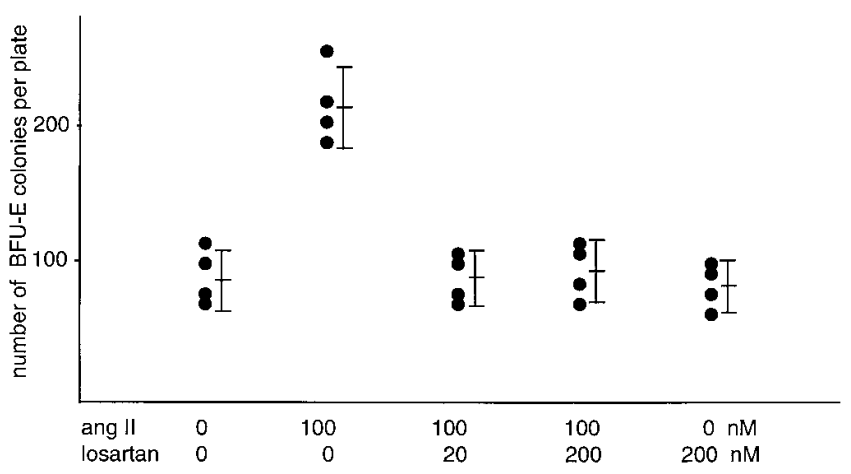

Figure 4. Stimulatory AngII effect inhibited by $\mathrm{AT}_{1}$ antagonist. The angiotensin II-mediated stimulatory effect on proliferation of early erythroid progenitors was blocked by losartan, an $\mathrm{AT}_{1}$-specific antagonist.

plant erythrocytosis patients in vitro to erythropoietin did not markedly differ compared to renal transplant recipients without erythrocytosis or normal volunteers (data not shown). The relative proportion of erythroid progenitors in renal transplant recipients with and without erythrocytosis is depicted in Fig. 5.

\section{Discussion}

Our data support the hypothesis that angiotensin II stimulates erythropoiesis, and that this effect is mediated through its $\mathrm{AT}_{1}$ receptor. The stimulatory effect of angiotensin II on erythropoiesis in vitro was observed only if the erythroid progenitors were cultured with erythropoietin, confirming the essential role of erythropoietin in erythropoiesis. Losartan (an $\mathrm{AT}_{1}$ antagonist) added to cultures of early erythroid progenitors inhibited the stimulatory effect. Coupled with the finding that losartan lowers hematocrit in patients with posttransplant erythrocytosis $(9,10)$, we conclude that the $\mathrm{AT}_{1}$ receptor signal transduction pathway plays a significant role in the pathogenesis of this clinically important complication.

A stimulatory effect of angiotensin II on erythropoiesis may be mediated by Jak-2 kinase. Binding of angiotensin to $\mathrm{AT}_{1}$ receptors on smooth muscle cells activates this kinase (18). Since $\mathrm{AT}_{1}$ receptors are present on erythroid progenitors,

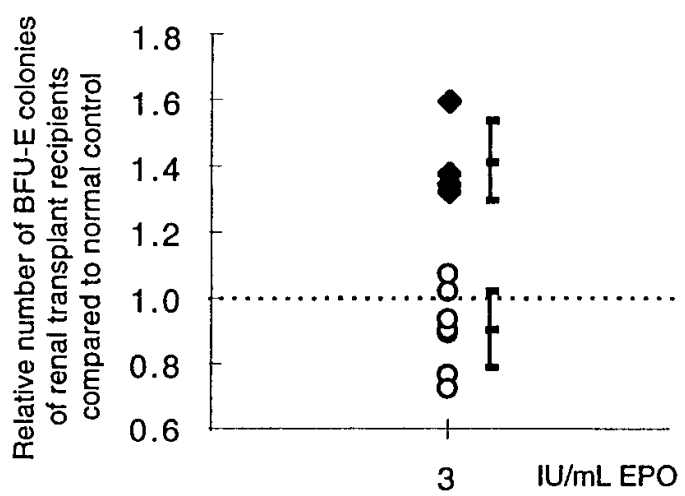

Figure 5. Assessment of circulating erythroid progenitors in peripheral blood. Posttransplant erythrocytosis patients (black diamonds) have more BFU-Es in peripheral blood than do renal transplant recipients without erythrocytosis (open circles) or normal controls (1.0). angiotensin II may stimulate erythroid proliferation directly, and augment the effect of either the erythropoietin signal transduction pathway or that of other erythroid growth factors that share Jak-2 kinase-mediated signal transduction pathways. These growth factors, including IL-3, stem cell factor, IGF-1, GM-CSF, IL-6, and erythropoietin (19-23), regulate erythropoiesis from the earliest erythroid progenitors to proerythroblasts. Our data suggest that angiotensin II likely increases proliferation of the earliest erythroid progenitors. Its effect on more committed progenitors was not pronounced because neither the number nor size of the colonies of more differentiated erythroid progenitors appreciably increased after angiotensin II stimulation.

Aberrant regulation in $\mathrm{AT}_{1}$ receptor signal transduction pathway in posttransplant erythrocytosis patients is supported by our finding of increased proportion of erythroid progenitors in their peripheral blood as compared to normal controls, as well as to renal transplant recipients who did not develop erythrocytosis (Fig. 5).

\section{References}

1. Cashman, J.D., A.C. Eaves, E.W. Raines, R. Ross, and C.J. Eaves. 1990. Mechanisms that regulate the cell cycle status of very primitive hematopoietic cells in long-term human marrow cultures. I. Stimulatory role of a variety of mesenchymal cell activators and inhibitory role of TGF-beta. Blood. 75:96-101.

2. Shao, L., N.L. Frigon, Jr., D.W. Sehy, A.L.Yu, J. Lofgren, R. Schwall, and J. Yu. 1992. Regulation of production of activin A in human marrow stromal cells and monocytes. Exp. Hematol. (NY). 20:1235-1242.

3. Clark, S.C., and R. Kamen. 1987. The human hematopoietic colony-stimulating factors. Science (Wash. DC). 236:1229-1237.

4. Bernstein, A., L. Forrester, A.D. Reith, P. Dubreuil, and R. Rottapel. 1991. The murine W/c-kit and Steel loci and the control of hematopoiesis. Semin. Hematol. 28:138-142.

5. Weber, H., D.S. Taylor, and C.J. Molloy. 1994. Angiotensin II induces delayed mitogenesis and cellular proliferation in rat aortic smooth muscle cells. Correlation with the expression of specific endogenous growth factors and reversal by suramin. J. Clin. Invest. 93:788-798.

6. Jackson, T.R., L.A. Blair, J. Marshall, M. Goedert, and M.R. Hanley. 1988. The mas oncogene encodes an angiotensin receptor. Nature (Lond.). 335: 437-440.

7. Julian, B.A., R.S. Gaston, C.V. Barker, G. Krystal, A.G. Diethelm, and J.J. Curtis. 1994. Erythropoiesis after withdrawal of enalapril in post-transplant erythrocytosis. Kidney Int. 46:1397-1403.

8. Danovitch, G.M., N.J. Jamgotchian, P.H. Eggena, W. Paul, J.D. Barrett, A. Wilkinson, and D.B.N. Lee. 1995. Angiotensin-converting enzyme inhibition in the treatment of renal transplant erythrocytosis. Clinical experience and observation of mechanism. Transplantation (Baltimore). 60:132-137.

9. Conlon, P.J., S.R. Smith, D.W. Butterly, and D.C. Brennan. 1996. Losartan in post transplant erythrocytosis. J. Am. Soc. Nephrol. (Abstr.). 7:1930.

10. Rivalan, J., M.P. Morin, V. Joyeux, and P. Le Pogamp. 1996. Posttransplant erythrocytosis treatment with losartan. J. Am. Soc. Nephrol. (Abstr.). 7: 1939.

11. Liu, Y., J. Phelan, R.C.P. Go, J.F. Prchal, and J.T. Prchal. 1997. Rapid determination of clonality by detection of two closely-linked $\mathrm{X}$ chromosome exonic polymorphisms using allele-specific PCR. J. Clin. Invest. 99:1984-1990.

12. Prchal, J.F., and A.A. Axelrad. 1974. Bone-marrow responses in polycythemia vera. N. Engl. J. Med. 289:1382.

13. Eaves, C.J., and A.C. Eaves. 1978. Erythropoietin (Ep) dose-response curves for three classes of erythroid progenitors in normal human bone marrow and in patients with polycythemia vera. Blood. 52:1196-1210.

14. Laemmli, U.K. 1970. Cleavage of structural proteins during the assembly of the head of bacteriophage T4. Nature (Lond.). 227:680-685.

15. Towbin, H., T. Staehelin, and J. Gordon. 1979. Electrophoretic transfer of proteins from polyacrylamide gels to nitrocellulose sheets: Procedure and some applications. Proc. Natl. Acad. Sci. USA. 76:4350-4354.

16. Prchal, J.F., J.W. Adamson, L. Steinman, and P.J. Fialkow. 1976. Human erythroid colony in vitro: evidence for clonal origin. J. Cell Physiol. 89: 489-492.

17. Shibata, H., H. Suzuki, M. Murakami, A. Sato, and T. Saruta. 1994. Angiotensin II type 1 receptor messenger RNA levels in human blood cells of patients with primary and secondary hypertension: reference to renin profile. $J$. Hypertens. 12:1275-1284.

18. Marrero, M.B., B. Schieffer, W.G. Paxton, L. Heerdt, B.C. Berk, P. Delafontaine, and K.E. Bernstein. 1995. Direct stimulation of Jak/STAT path- 
way by the angiotensin II AT1 receptor. Nature (Lond.). 273:247-250.

19. Wang, Y., K.K. Morella, J. Ripperger, C.F. Lai, D.P. Gearing, G.H.

Few, S.P. Campos, and H. Baumann. 1995. Receptors for interleukin-3 (IL-3) and growth hormone mediate an IL-6-type transcriptional induction in the presence of JAK2 or STAT3. Blood. 86:1671-1679.

20. Linnekin, D., S.R. Weiler, S. Mou, C.S. DeBerry, J.R. Keller, F.W. Ruscetti, D.K. Ferris, and D.L. Longo. 1996. JAK2 is constitutively associated with c-Kit and is phosphorylated in response to stem cell factor. Acta. Haematol. (Basel). 95:224-228.

21. Quelle, F.W., N. Sato, B.A. Witthuhn, R.C. Inhorn, M. Eder, A. Miyajima, J.D. Griffinand, and J.N. Ihle. 1994. JAK2 associates with the beta c chain of the receptor for granulocyte-macrophage colony-stimulating factor, and its activation requires the membrane-proximal region. Mol. Cell. Biol. 14:43354341.

22. Wang, Y., and G.M. Fuller. 1994. Phosphorylation and internalization of gp130 occur after IL-6 activation of Jak2 kinase in hepatocytes. Mol. Biol. Cell. 5:819-828.

23. Jiang, N., T.C. He, A. Miyajima, and D.M. Wojchowski. 1996. The box1 domain of the erythropoietin receptor specifies Janus kinase 2 activation and functions mitogenically within an interleukin 2 beta-receptor chimera. J. Biol. Chem. 271:16472-16476. 